\title{
EVALUASI KINERJA SAHAM BERTANGGUNGJAWAB SOSIAL (STUDI PADA SAHAM-SAHAM YANG MASUK PERHITUNGAN INDEKS SRI-KEHATI)
}

\author{
Angriana Lakaba \\ Robiyanto \\ Fakultas Ekonomika dan Bisnis Universitas Kristen Satya Wacana Salatiga \\ Email: robiyanto@staff.uksw.edu
}

\begin{abstract}
Severals studies on the performance of stocks, especially those that examine the constituent of social responsibility in the Indonesia Stock Exchange, in general still focus on the performance assessment of the SRI-Kehati Index, have not specifically reviewed the performance of the constituent stocks of the SRI-Kehati Index. Therefore, this study specifically examines constituent stocks of the SRI-Kehati Index. The study period used is 2009 to 2017. The sample in this study are 13 stocks that consistently enter into the calculation of SRI-Kehati Index during the study period. The stock performance assessment will be performed using Sharpe Index, Jensen Alpha, Treynor Ratio, Sortino Ratio, Information Ratio. Overall, the consistent stocks listed in the SRI-Kehati Index may not necessarily indicate good stock performance. From 13 stocks, some have negative results which can be classified as non-performing stock.
\end{abstract}

Keywords: SRI-Kehati, Sharpe Index, Jensen Alpha, Treynor Ratio, Sortino Ratio, Information Ratio

\begin{abstract}
ABSTRAK
Berbagai penelitian terkait kinerja saham-saham bertanggungjawab sosial di Bursa Efek Indonesia secara umum masih berfokus pada penilaian kinerja Indeks SRI-Kehati, namun belum secara khusus mengkaji kinerja saham-saham pembentuk Indeks SRI-Kehati. Oleh sebab itu penelitian ini secara khusus mengkaji saham-saham pembentuk Indeks SRIKehati. Periode penelitian yang digunakan adalah periode tahun 2009 hingga tahun 2017. Sampel dalam penelitian ini adalah 13 saham yang secara konsisten masuk ke dalam perhitungan Indeks SRI-Kehati selama periode penelitian. Penilaian kinerja saham akan dilakukan dengan menggunakan Indeks Sharpe, Jensen Alpha, Rasio Treynor, Rasio Sortino, Information Ratio. Secara keseluruhan, saham-saham yang konsisten terdaftar dalam Indeks SRI-Kehati belum semua menunjukkan kinerja saham yang baik. Dari 13 saham yang diteliti masih ada beberapa saham dengan hasil negatif yang berarti masih mempunyai kinerja saham yang buruk.

Kata kunci: SRI-Kehati, Indeks Sharpe, Jensen Alpha, Rasio Treynor, Rasio Sortino, Information Ratio
\end{abstract}

Investasi yang bertanggungjawab sosial saat ini menjadi suatu tren di pasar modal global dan tak terkecuali di Indonesia. Investor tidak sekedar mengejar imbal hasil (return) yang tinggi melainkan juga melakukan investasi pada saham yang berwawasan sosial dan lingkungan (Fernita, 
Paramita, Restuti, \& Nugroho, 2014). Hal yang sama terjadi pada konsumen produk-produk yang berwawasan lingkungan (Sanidewi \& Paramita, 2018). Berkaitan dengan keputusan investasi, saat ini investor menggunakan kombinasi antara kriteria keuangan dan sosial yang dikenal dengan Socially Responsible Investment (SRI). Investasi bertanggungjawab sosial juga terjadi di Indonesia dengan terciptanya indeks yang disebut Indeks SRI-Kehati yang bekerja sama dengan BEI (Robiyanto, 2018). Terciptanya Indeks SRI-Kehati dipicu oleh kerusakan lingkungan. Keberadaan Indeks SRIKehati diharapkan sebagai indeks etika bagi investor SRI agar dapat meninjau kembali kinerja profitabilitas perusahaan yang didukung dengan kinerja enviromental, social, and governance (ESG).

Dalam melakukan investasi pada instrumen saham, investor sering kali dihadapkan pada adanya ketidakpastian yang ditimbulkan karena adanya variabilitas return (Robiyanto, 2017). Variabilitas return tersebut menyebabkan return saham pada suatu periode mengandung volatilitas dan sulit diprediksi (Panait \& Slavescu, 2012; Robiyanto \& Hartanto, 2018). Agar dapat mengurangi risiko atau meminimalkan potensi kerugian potensial yang dapat ditanggung dalam berinvestasi, maka investor perlu melakukan analisis kinerja saham. Semua instrumen investasi (kecuali instrumen investasi bebas risiko) memiliki risiko, tak terkecuali saham-saham bertanggungjawab sosial.

Beberapa penelitian yang mengkaji kinerja saham-saham bertanggungjawab sosial diantaranya dilakukan oleh Adam dan Shauki (2014) yang mengkaji perilaku proses pengambilan keputusan investor SRI dengan menggunakan Jensen Alpha untuk portofolio saham SRI dan konvensional dari negara-negara Asia Pasifik (Australia, Jepang, Malaysia, dan Singapura). Penelitian lainnya dilakukan oleh Zulkafli, Ahmad, dan M. (2017) yang membandingkan kinerja saham-saham anggota Indeks SRI-Kehati dan Jakarta Composite Index (JCI). Hasil penelitian Zulkafli, Ahmad, dan M. (2017) menunjukkan bahwa kinerja Indeks SRI-Kehati lebih rendah dibandingkan $\mathrm{JCl}$ jika dibandingkan dengan menggunakan Indeks Sharpe. Namun berdasarkan pengukuran Rasio Treynor, Jensen Alpha, dan Rasio Sortino menunjukkan bahwa kinerja Indeks SRI-Kehati lebih baik daripada JCl. Hal ini juga didukung oleh hasil penelitian Robiyanto $(2017,2018)$ yang menemukan bahwa Indeks SRI-Kehati memiliki kinerja yang lebih baik dibandingkan dengan indeks pasar saham bahkan indeks saham-saham likuid.

Berbagai penelitian yang telah disebutkan di atas secara umum fokus pada penilaian kinerja Indeks SRI-Kehati, belum secara khusus mengkaji kinerja saham-saham pembentuk Indeks SRIKehati ataupun indeks saham-saham SRI. Lebih lanjut penelitian yang telah dilakukan hanya berfokus pada pengukuran dengan menggunakan Indeks Sharpe, Jensen Alpha dan Rasio Treynor, belum banyak yang menggunaan pengukuran kinerja saham lainnya seperti Rasio Sortino dan Information Ratio. Oleh sebab itu, penelitian ini akan mengevaluasi kinerja saham-saham Indeks SRI-Kehati dengan menggunakan alat pengukuran Indeks Sharpe, Jensen Alpha, Rasio Treynor, Rasio Sortino dan Information Ratio. Kedua alat pengukuran yang terakhir masih jarang digunakan dalam pengukuran kinerja saham. Penelitian ini diharapkan dapat membantu investor dalam membuat keputusan investasi yang baik dengan risk-return terbaik pada saham-saham pembentuk Indeks SRI-Kehati yang sadar lingkungan, peduli terhadap sosial, dan memiliki tata kelola perusahaan yang baik.

\section{KAJIAN PUSTAKA}

\section{Socially Responsible Investment}

Ekonomi Neoklasik mengasumsikan bahwa investor mempertimbangkan dua hal dalam keputusan investasi yaitu risiko dan return yang diharapkan (Hickman, Teets, \& Kohls, 1999). Perspektif SRI (Socially Responsible Investment), tidak hanya berpusat pada hubungan return dan 
risiko investasi, namun juga dampak investasi pada ESG (environmental, social and governance). Menurut Plantinga dan Scholtens (2001), tujuan investor SRI juga dapat dilihat dari dampak investasi terhadap masyarakat. Investor SRI menghindari perusahaan maupun industri yang memproduksi barang yang terkait dengan skrining negatif. Investor memilih perusahaan yang memberikan dampak positif terhadap lingkungan sosial, lingkungan dan tata kelola yang baik (Renneboog, ter Horst, \& Zhang, 2008). Hal ini sesuai dengan teori triple bottom line (profit, people, and planet) yang menyatakan bahwa planet untuk lingkungan, orang-orang untuk sosial dan keuntungan untuk pemerintahan.

Para investor memiliki alasan bahwa mereka tidak hanya mempertimbangkan financial return tapi juga peduli akan pentingnya nilai sosial, tempat usaha, karakteristik barang atau jasa perusahaan, dan bagaimana bisnis dijalankan. Inilah alasan mengapa fokus pada motivasi investor SRI memerlukan perubahan pada pola pikir dan keyakinan pribadi mereka terhadap lingkungan, sosial dan tata kelola yang lebih baik tanpa melupakan risiko dan pengembalian investasi (Zulkafli, Ahmad, \& M., 2017).

\section{SRI-Kehati (Keanekaragaman Hayati Indonesia)}

Indeks SRI-Kehati diperkenalkan di masyarakat sejak 8 Juni 2009. Indeks ini dibentuk mengacu pada tata cara SRI. Indeks SRI-Kehati dibuat oleh Yayasan Kehati yang bekerjasama dengan PT Bursa Efek Indonesia (BEI). Tahun dasar yang digunakan sebagai tahun awal indeks dengan basis 100 (seratus) adalah pada 30 Desember 2006 dan dipublikasikan oleh BEI sebagai Indeks SRI-Kehati yang berada di posisi 116,946. Tujuan diperkenalkannya Indeks SRI-Kehati adalah agar masyarakat memiliki lebih banyak lagi pilihan alternatif investasi khususnya investasi dalam indeks dimana indeks ini menggambarkan perusahaan-perusahaan yang menguntungkan secara ekonomi dengan memperhatikan kelestarian lingkungan hidup.

Mekanisme pemilihan perusahaan-perusahaan untuk masuk Indeks SRI-Kehati dilakukan dua kali setahun melalui dua tahap, tahap pertama adalah proses awal seleksi negatif dan dari aspek keuangan kemudian tahap kedua yaitu dengan aspek fundamental. Penilaian dilakukan dengan cara review terhadap data sekunder juga pengisian kuesioner oleh perusahaan-perusahaan yang sudah melalui berbagai tahapan seleksi di atas, dan data-data lain yang relevan.

\section{Pengukuran Kinerja Saham}

Pengukuran umum kinerja saham adalah Indeks Sharpe, Rasio Treynor, Jensen Alpha, Rasio Sortino, dan Information ratio yang semuanya memiliki tujuan khusus dalam menjelaskan risiko dan return. Sebagian besar penelitian menggunakan model ini dalam mengukur kinerja SRI.

\section{Indeks Sharpe}

Indeks Sharpe merupakan salah satu cara yang digunakan dalam membandingkan kinerja portofolio yang menggunakan konsep garis pasar modal/Capital Market Line dan juga dikenal dengan istilah Reward to Variability (RVAR) (Pangestuti, Wahyudi, \& Robiyanto, 2017).Dalam perkembangannya Indeks Sharpe juga dapat digunakan untuk mengkaji kinerja saham atau pun reksa dana. Ferruz, Gómez-Bezares, dan Vargas (2010) mendefinisikan Indeks Sharpe sebagai perhitungan dalam pengukuran return aset portofolio bebas risiko yang terkait dengan total risiko. Pengukuran Indeks Sharpe bertujuan untuk mengevaluasi portofolio atau saham individu dengan risiko yang tidak bisa didiversifikasi (diversifiable risk) (Putra, Atahau, \& Robiyanto, 2018). 


\section{Rasio Treynor}

Rasio Treynor dikembangkan oleh Treynor (1965), dan rasio ini juga sering disebut dengan Reward to Volatility Ratio (RVOL) (Robiyanto, Wahyudi, \& Pangestuti, 2017). Cara untuk mengukur Rasio Treynor ini sama dengan menghitung Indeks Sharpe yang digunakan untuk mengukur kinerja saham atau portofolio tetapi risiko yang digunakan adalah beta saham atau beta portofolio. Hal itu terjadi karena yang digunakan sebagai patokan dalam Rasio Treynor adalah persamaan garis sekuritas (security market line). Asumsi yang digunakan oleh Treynor yaitu bahwa portofolio atau saham sudah terdiversifikasi secara baik sehingga risiko yang digunakan adalah beta.

\section{Jensen Alpha}

Jensen Alpha (differential return measure) adalah salah satu ukuran kinerja saham atau kinerja portofolio yang sangat memperhatikan Capital Aset Pricing Model (CAPM) (Jensen, 1967). Jensen Alpha merupakan sebuah ukuran saham atau portofolio yang mengestimasikan return konstan selama periode investasi dengan risiko sistematik yang sama (Zulkafli, Ahmad, \& M., 2017). Pengukuran Jensen juga digunakan untuk mengidentifikasi apakah indeks berkinerja baik atau bahkan berkinerja buruk dengan portofolio pasar.

\section{Rasio Sortino}

Rasio Sortino berfokus pada apakah suatu risiko menguntungkan apabila dilihat dari tingkat bebas risiko (Sortino \& Price, 1994). Dalam perkembangannya Rasio Sortino selain digunakan untuk mengukur kinerja saham juga dapat digunakan untuk mengukur kinerja saham. Rumusnya hampir sama dengan Rasio Sharpe, namun risiko diukur dengan penyimpangan risiko downside (Rollinger \& Hoffman, 2013). Nilai Rasio Sortino yang besar menunjukkan probabilitas rendah dari kerugian yang besar (Zulkafli, Ahmad, \& M., 2017).

\section{Information Ratio}

Information Ratio (IR) yang juga sering disebut dengan Appraisal Ratio maupun rasio penilaian (Kidd, 2011). Nilai dari Information Ratio mengukur return yang tidak normal per unit risiko kemudian dapat didiversifikasi dengan adanya portofolio pasar. Information Ratio merupakan perluasan dari Rasio Sharpe dengan risiko bebas yang diganti dengan portofolio acuan (Nadifa, 2016). Information Ratio menggunakan pembanding yaitu risiko yang aktif atau tracking error. Di mana tracking error adalah ukuran yang digunakan dalam menilai suatu kinerja portofolio yang relatif terhadap benchmark (Blatt, 2004).

\section{METODE PENELITIAN Jenis dan Sumber Data}

Data yang digunakan dalam penelitian ini adalah data sekunder, yang merupakan data historis berupa indeks penutupan bulanan saham perusahaan yang konsisten dalam Indeks SRIKehati tahun 2009-2017, data tingkat suku bunga BI rate, dan data indeks harga saham gabungan yang diperoleh dari www.finance.yahoo.com dan www.bi.go.id.

\section{Populasi dan Sampel Penelitian}

Populasi dalam penelitian ini adalah saham-saham yang masuk dalam Indeks SRI-Kehati. Sampel dalam penelitian ini diambil dengan menggunakan metode purposive sampling dengan 
kriteria konsisten masuk dalam perhitungan Indeks SRI-Kehati selama periode 2009-2017. Nama saham yang menjadi sampel dapat dilihat pada Tabel 1.

Tabel 1. Saham-Saham yang Konsisten Terdaftar dalam Indeks SRI-Kehati 2009-2017

\begin{tabular}{ll}
\hline Kode Saham & Nama Perusahaan \\
\hline AALI & PT. Astra Agro Lestari Tbk. \\
ASII & PT. Astra Internasional Tbk. \\
BBCA & PT. Bank Central Asia Tbk. \\
BBRI & PT. Bank Rakyat Indonesia (Persero) Tbk. \\
BDMN & PT. Bank Danamon Indonesia Tbk. \\
BMRI & PT. Bank Mandiri (Persero) Tbk. \\
INDF & PT. Indofood Sukses Makmur Tbk. \\
KLBF & PT. Kalbe Farma Tbk. \\
PGAS & PT. Perusahaan Gas Negara (Persero) Tbk. \\
TINS & PT. Timah (Persero) Tbk. \\
TLKM & PT. Telekomunikasi Indonesia (Persero) Tbk. \\
UNTR & PT. United Tractors Tbk. \\
UNVR & PT. Unilever Indonesia Tbk.
\end{tabular}

\section{Teknik Analisis}

Indeks Sharpe (RVAR) merupakan metode yang digunakan dalam mengukur kinerja saham yang didasarkan pada seberapa besar return investasi yang diperoleh untuk setiap unit risiko yang diambil atau perbandingan rata-rata antara selisih return saham dan return bebas risiko dengan risiko total portofolio atau suatu saham. Rumusnya adalah sebagai berikut (Robiyanto, 2018):

$$
\mathrm{RVAR}=\frac{R_{i}-R F R}{\sigma_{\mathrm{i}}}
$$

Keterangan :

$\mathrm{R}_{\mathrm{i}} \quad=$ Average stock return

$\mathrm{RFR}=$ Risk free rate diwakili oleh $\mathrm{BI}$ Rate

$\sigma_{i} \quad=$ Standard deviation stock

Rasio Treynor (RVOR) yaitu metode yang menggunakan beta $(\beta)$ yang merupakan risiko fluktuatif yang relatif terhadap risiko pasar atau perbandingan rata-rata antara selisih return portofolio atau saham dan return bebas risiko dengan beta portofolio atau saham. Rumusnya adalah sebagai berikut (Putra, Atahau, \& Robiyanto, 2018):

$$
\mathrm{RVOL}=\frac{R_{i}-R F R}{\beta_{\mathrm{i}}}
$$

Keterangan :

$\mathrm{R}_{\mathrm{i}} \quad=$ Average stock return

$\mathrm{RFR}=$ Risk free rate diwakili oleh $\mathrm{BI}$ Rate

$\beta_{\mathrm{i}} \quad=$ Beta of stock 
Sedangkan beta saham dihitung menggunakan rumus sebagai berikut:

$$
\beta=\frac{\operatorname{Cov}\left(R_{i}, R_{m}\right)}{\sigma^{2} R_{m}}
$$

Keterangan :

$\beta_{i} \quad=$ Beta of stock

$\operatorname{Cov}\left(R_{i}, R_{m}\right)=$ Covariance of stock return and market return

$\sigma^{2} R_{m} \quad=$ Market return variance

Jensen Alpha $\left(\alpha_{P}\right)$ yaitu metode yang digunakan untuk menilai kinerja investasi yang dapat memberikan kinerja di atas kinerja pasar yang sesuai dengan risiko yang dihadapi. Rumusnya adalah sebagai berikut (Jensen, 1967):

$$
\alpha_{\mathrm{p}}=\mathrm{R}_{\mathrm{i}}-\left[\mathrm{RFR}+\beta_{\mathrm{i}}\left(R_{m}-R F R\right)\right]
$$

Keterangan :

$\mathrm{R}_{\mathrm{i}} \quad=$ Average stock return

$\mathrm{RFR}=$ Risk free rate diwakili oleh $\mathrm{BI}$ Rate

$\beta_{\mathrm{i}} \quad=$ Beta of stock

$\mathrm{R}_{\mathrm{m}} \quad=$ Market return

Rasio Sortino (SoM) memberikan gambaran yang lebih realistis mengenai suatu risiko pada dana atau saham. Rasio Sortino yang besar menunjukkan adanya kemungkinan menyebabkan kerugian yang lebih besar. Rumusnya adalah sebagai berikut (Robiyanto, 2018):

$$
\mathrm{SoM}=\frac{R_{i}-R F R}{\sigma}
$$

Keterangan :

$\mathrm{R}_{\mathrm{i}} \quad=$ Average stock return

$\mathrm{RFR}=$ Risk free rate diwakili oleh $\mathrm{BI}$ Rate

Dimana $\sigma$ adalah downside deviation dari return pasar saham untuk periode tertentu yang dihitung dengan rumus sebagai berikut (Robiyanto, 2018):

Keterangan:

$$
\sigma=\frac{\sqrt{£(\min R p M A R, 0) 2}}{N-1}
$$

$\sigma=$ Downside deviation

$R p=$ Stock return (Index)

MAR = Minimum Acceptable Return = risk-free rate

$\mathrm{N}=$ Number of observations

Dengan ketentuan sebagai berikut:

Jika (Rp-MAR) negatif, maka gunakan nilai (Rp-MAR)

Jika (Rp-MAR) positif, maka gunakan nilai 0 
Pengukuran Information Ratio (IR) adalah rasio antara alpha dan risiko dari suatu saham atau risiko non-sistematik saham yang sering disebut tracking error dari sebuah industri (Kidd, 2011).

$$
I R=\frac{\alpha}{\sigma_{e p}}
$$

Keterangan :

$\mathrm{IR}=$ Information Ratio

$\alpha=$ Nilai jensen alpha

$\sigma_{\mathrm{ep}}=$ Risiko untuk saham

\section{HASIL DAN PEMBAHASAN}

\section{Kinerja Saham dengan Indeks Sharpe}

Pengukuran dengan menggunakan Indeks Sharpe atau RVAR menekankan pada risiko total atau standar deviasi. Standar deviasi yang menyatakan besar atau kecilnya perubahan return suatu saham terhadap rata-rata return saham yang berkaitan. Data masa lalu digunakan untuk memprediksi kinerja saham dimasa yang akan datang. Rata-rata return masa lalu dianggap sebagai return prediksi masa datang dan standar deviasi return masa lalu dianggap sebagai risiko masa datang. Data average stock return, standar deviasi, dan risk free rate hasil perhitungan kinerja 13 saham yang konsisten dalam Indeks SRI-Kehati periode tahun 2009-2017 serta pengukuran Indeks Sharpe dari masing-masing saham tersebut dapat dilihat dalam Tabel 2.

Tabel 2. Kinerja Saham dengan Indeks Sharpe Periode Tahun 2009-2017

\begin{tabular}{ccccccccccc}
\hline $\begin{array}{c}\text { Kode } \\
\text { Saham }\end{array}$ & 2009 & 2010 & 2011 & 2012 & 2013 & 2014 & 2015 & 2016 & 2017 & All Period \\
\hline AALI & 0,705 & $-0,092$ & $-0,140$ & $-0,121$ & 0,102 & 0,040 & $-0,206$ & $-0,016$ & $-0,733$ & $-0,051$ \\
ASII & 0,543 & 0,247 & 0,673 & $-0,114$ & $-0,240$ & 0,233 & $-0,184$ & 0,224 & 0,023 & 0,156 \\
BBCA & 0,859 & 0,095 & 0,435 & 0,208 & $-0,005$ & 0,391 & $-0,124$ & 0,193 & 0,753 & 0,312 \\
BBRI & 0,079 & 0,314 & $-0,142$ & 0,130 & 0,239 & 0,518 & 0,327 & 0,407 & 0,265 & 0,237 \\
BDMN & $-0,058$ & 0,180 & $-0,313$ & 0,272 & $-0,283$ & $-0,070$ & $-0,023$ & 0,018 & 0,382 & 0,012 \\
BMRI & 0,221 & 0,185 & 0,105 & 0,298 & $-0,038$ & 0,472 & 0,085 & 0,113 & 0,894 & 0,260 \\
INDF & 0,887 & 0,226 & $-0,003$ & 0,365 & 0,117 & 0,027 & $-0,172$ & 0,239 & $-0,144$ & 0,171 \\
KLBF & 0,278 & 0,409 & 0,242 & 0,481 & 0,206 & 0,590 & $-0,595$ & 0,061 & 0,287 & 0,218 \\
PGAS & 0,204 & 0,090 & $-0,169$ & 0,325 & 0,002 & 0,001 & $-0,474$ & 0,128 & $-0,420$ & $-0,035$ \\
TINS & 0,088 & 0,149 & $-0,330$ & $-0,077$ & $-0,143$ & 0,210 & $-0,732$ & 0,386 & $-0,175$ & $-0,069$ \\
TLKM & 0,058 & $-0,335$ & $-0,443$ & 0,340 & 0,148 & 0,232 & 0,153 & 0,164 & 0,177 & 0,055 \\
UNTR & 0,603 & 0,241 & 0,290 & $-0,251$ & $-0,109$ & $-0,192$ & $-0,107$ & 0,235 & 0,856 & 0,174 \\
UNVR & $-0,087$ & 0,258 & 0,289 & 0,102 & 0,242 & 0,359 & $-0,064$ & 0,094 & 0,596 & 0,199 \\
\hline
\end{tabular}

Sumber: Data sekunder, diolah.

Tabel 2. memperlihatkan bahwa hasil nilai minimal perhitungan Indeks Sharpe dari periode tahun 2009 sampai dengan tahun 2017 adalah sebesar -0,733 yang ditemukan pada emiten AALI dan nilai maksimal yaitu 0,894 ditemukan pada emiten BMRI pada tahun 2017. Sedangkan yang memperoleh nilai rata-rata terbaik berdasarkan hasil perhitungan Indeks Sharpe yaitu BBCA dengan nilai rata-rata sebesar 0,312. Jika nilai dari Indeks Sharpe/RVAR positif atau semakin besar maka 
kinerja saham semakin baik. Pada periode tahun 2009-2017, terdapat hasil perhitungan Indeks Sharpe ada yang bernilai negatif. Hal tersebut berarti bahwa saham-saham dalam Indeks SRI-Kehati tidak semuanya baik karena belum semuanya bernilai positif. Emiten yang memperoleh nilai rata-rata terbaik berdasarkan hasil perhitungan Indeks Sharpe yaitu BBCA dengan nilai rata-rata sebesar 0,312 . Sedangkan ada 3 saham yang berdasarkan rata-rata menunjukkan kinerja Sharpe negatif antara lain: AALI, PGAS, dan TINS.

\section{Kinerja Saham dengan Rasio Treynor}

Pengukuran kinerja saham dengan menggunakan Rasio Treynor atau RVOL menggunakan return rata-rata dan menggunakan beta sebagai tolak ukur risiko. Besar kecilnya nilai beta menunjukkan perubahan return dari suatu saham terhadap perubahan return pasar. Beta digunakan sebagai tolak ukur risiko investasi karena fluktuasi harga saham pada umumnya dipengaruhi oleh fluktuasi pasar. Jika beta < 1 artinya risiko saham lebih kecil daripada risiko pasar. Sebaliknya jika nilai beta > 1 maka risiko saham lebih besar dari risiko pasar. Pada Tabel 3 dapat dilihat hasil pengukuran kinerja saham pada 13 saham yang konsisten masuk ke dalam Indeks SRI-Kehati periode tahun 2009-2017 dengan menggunakan Rasio Treynor.

Tabel 3. Kinerja Saham dengan Rasio Treynor Periode Tahun 2009 sampai 2017

\begin{tabular}{ccccccccccc}
\hline $\begin{array}{c}\text { Kode } \\
\text { Saham }\end{array}$ & 2009 & 2010 & 2011 & 2012 & 2013 & 2014 & 2015 & 2016 & 2017 & All Period \\
\hline AALI & $-0,067$ & $-0,011$ & 0,004 & 0,001 & 0,026 & 0,025 & $-0,044$ & 0,007 & $-0,021$ & $-0,006$ \\
ASII & 0,019 & 0,017 & 0,039 & $-0,006$ & $-0,020$ & 0,006 & $-0,009$ & 0,007 & 0,001 & 0,006 \\
BBCA & 0,095 & 0,008 & 0,038 & 0,025 & 0,000 & 0,164 & $-0,006$ & 0,007 & 0,025 & 0,017 \\
BBRI & 0,005 & $-0,043$ & $-0,025$ & 0,006 & 0,044 & 0,014 & $-0,039$ & $-0,082$ & $-0,030$ & $-0,079$ \\
BDMN & $-0,002$ & 0,029 & $-0,035$ & 0,022 & $-0,019$ & 0,002 & $-0,001$ & 0,001 & 0,012 & 0,002 \\
BMRI & 0,013 & 0,053 & 0,028 & 0,037 & $-0,002$ & 0,012 & 0,047 & 0,004 & 0,064 & 0,012 \\
INDF & 0,048 & 0,021 & 0,000 & 0,029 & 0,011 & 0,001 & $-0,017$ & 0,010 & $-0,006$ & 0,011 \\
KLBF & 0,015 & 0,059 & 0,019 & 0,043 & 0,016 & 0,110 & 0,110 & 0,002 & 0,016 & 0,016 \\
PGAS & 0,012 & 0,016 & $-0,011$ & 2,788 & 0,000 & 0,000 & $-0,031$ & 0,013 & $-0,033$ & $-0,007$ \\
TINS & 0,004 & 0,012 & $-0,020$ & $-0,004$ & 0,030 & 0,004 & $-0,160$ & $-0,068$ & 0,010 & $-0,003$ \\
TLKM & 0,004 & $-0,038$ & 0,065 & 0,023 & 0,012 & 0,021 & 0,010 & 0,007 & 0,012 & 0,007 \\
UNTR & 0,027 & 0,019 & 0,019 & $-0,014$ & $-0,028$ & $-0,011$ & $-0,011$ & 0,022 & 0,061 & 0,010 \\
UNVR & $-0,006$ & 0,038 & $-0,041$ & $-0,056$ & 0,035 & 0,023 & $-0,022$ & 0,005 & 0,015 & 0,019 \\
\hline Sumber: Data sekunder, diolah & & & & & & & &
\end{tabular}

Tabel 3 menunjukkan bahwa Rasio Treynor periode tahun 2009-2017 terendah adalah sebesar $-0,160$ pada tahun 2015 pada emiten TINS, sedangkan nilai maksimal yaitu sebesar 2,788 pada tahun 2012 ditemukan pada emiten PGAS. Jika nilai Rasio Treynor/RVOL positif artinya kinerja saham semakin baik. Dan berdasarkan nilai rata-rata pengukuran Rasio Treynor, saham terbaik yaitu UNVR dengan nilai rata-rata Rasio Treynor sebesar 0,019. Sedangkan hasil perhitungan menggunakan Rasio Treynor dapat dilihat di setiap tahunnya ada yang bernilai negatif. Hal ini menunjukkan bahwa saham-saham dalam Indeks SRI-Kehati tersebut berdasarkan pengukuran kinerja Rasio Treynor belum semuanya baik karena secara merata nilainya belum semua positif. Dari 
Tabel 3 dapat dilihat bahwa 4 dari 13 saham yang konsisten dalam Indeks SRI-Kehati yang menunjukkan kinerja negatif. Saham-saham tersebut adalah AALI, BBRI, PGAS, dan TINS.

\section{Kinerja Saham dengan Jensen Alpha}

Hasil perhitungan kinerja saham dari 13 saham yang konsisten dalam Indeks SRI-Kehati periode tahun 2009-2017 dengan menggunakan metode Jensen Alpha dapat dilihat pada Tabel 4.

Tabel 4. Kinerja Saham dengan Jensen Alpha Periode Tahun 2009 sampai 2017

\begin{tabular}{ccccccccccc}
\hline $\begin{array}{c}\text { Kode } \\
\text { Saham }\end{array}$ & 2009 & 2010 & 2011 & 2012 & 2013 & 2014 & 2015 & 2016 & 2017 & All Period \\
\hline AALI & 0,030 & 0,011 & 0,004 & 0,001 & 0,026 & 0,025 & $-0,044$ & 0,007 & $-0,021$ & $-0,002$ \\
ASII & 0,059 & 0,059 & 0,049 & 0,005 & $-0,013$ & 0,036 & $-0,043$ & 0,033 & 0,021 & 0,005 \\
BBCA & 0,056 & 0,034 & 0,038 & 0,025 & $-0,001$ & 0,027 & $-0,017$ & 0,023 & 0,049 & 0,014 \\
BBRI & 0,017 & 0,187 & $-0,020$ & 0,027 & 0,275 & 0,044 & 0,750 & 0,772 & 0,184 & 0,256 \\
BDMN & 0,023 & 0,030 & $-0,013$ & 0,035 & $-0,031$ & $-0,011$ & $-0,035$ & 0,022 & 0,112 & 0,002 \\
BMRI & 0,038 & 0,053 & 0,028 & 0,037 & $-0,007$ & 0,031 & 0,024 & 0,026 & 0,043 & 0,014 \\
INDF & 0,106 & 0,045 & 0,017 & 0,023 & 0,010 & 0,017 & $-0,029$ & 0,036 & 0,013 & 0,009 \\
KLBF & 0,055 & 0,076 & 0,026 & 0,044 & 0,020 & 0,026 & $-0,037$ & 0,025 & 0,023 & 0,016 \\
PGAS & 0,023 & 0,018 & 0,000 & 0,030 & 0,003 & 0,014 & $-0,084$ & 0,031 & $-0,022$ & $-0,007$ \\
TINS & 0,036 & 0,058 & $-0,014$ & 0,009 & $-0,010$ & 0,009 & $-0,068$ & 0,057 & $-0,038$ & $-0,005$ \\
TLKM & 0,020 & $-0,005$ & $-0,009$ & 0,039 & 0,011 & 0,026 & 0,001 & 0,022 & 0,026 & 0,008 \\
UNTR & 0,069 & 0,039 & 0,041 & $-0,012$ & $-0,002$ & 0,004 & $-0,015$ & 0,032 & 0,055 & 0,008 \\
UNVR & 0,016 & 0,039 & 0,021 & 0,012 & 0,022 & 0,022 & 0,001 & 0,021 & 0,051 & 0,016 \\
\hline Sumber: Data sekunder didlah & & & & & & & & &
\end{tabular}

Sumber: Data sekunder, diolah.

Tabel 4 menunjukkan bahwa nilai pengukuran menggunakan Jensen Alpha periode tahun 2009-2017 yang terkecil adalah sebesar -0,084 yang ditemukan pada saham emiten PGAS pada tahun 2015. Sedangkan nilai maksimum adalah sebesar 0,772 yang ditemukan pada saham BBRI pada tahun 2016. Kinerja saham dikategorikan baik jika nilai Jensen Alpha positif. Dan sebaliknya jika nilai Jensen Alpha negatif maka kinerja saham tersebut lebih rendah daripada indeks pasar. Hasil perhitungan Jensen Alpha periode tahun 2009-2017 menunjukkan bahwa masih ada 3 saham yang menunjukkan kinerja buruk yaitu AALI, PGAS, dan TINS. Sedangkan berdasarkan nilai rata-rata hasil pengukuran Jensen Alpha, saham yang terbaik adalah BBRI dengan nilai rata-rata sebesar 0,256 .

\section{Kinerja Saham dengan Information Ratio}

Hasil pengukuran kinerja saham-saham yang konsisten dalam Indeks SRI-Kehati dengan menggunakan Information Ratio dapat dilihat pada Tabel 5. Nilai minimum dari hasil perhitungan Information Ratio adalah sebesar -444 pada tahun 2010 yang terjadi pada emiten TLKM, sedangkan nilai maksimum adalah sebesar 4,328 pada tahun 2011 yang ditemukan pada emiten ASII. Nilai Information Ratio yang positif menunjukkan saham-saham tersebut mampu mengalahkan Benchmark atau lebih besar dari nilai pasar (0). Sebaliknya jika nilai Information Ratio negatif, maka saham tersebut lebih kecil dari nilai pasar (0). Tabel 5 juga menunjukkan bahwa tidak semua saham memiliki 
nilai Information Ratio yang positif. Terdapat 5 saham yang menunjukkan kinerja yang lebih kecil dari nilai pasar yaitu AALI, BDMN, PGAS, TINS, dan TLKM. Berdasarkan nilai rata-rata hasil pengukuran Information Ratio, saham yang terbaik yaitu BBCA dengan nilai rata-rata sebesar 0,442.

Tabel 5. Kinerja Saham dengan Information Ratio Periode Tahun 2009 sampai 2017

\begin{tabular}{|c|c|c|c|c|c|c|c|c|c|c|}
\hline $\begin{array}{l}\text { Kode } \\
\text { Saham }\end{array}$ & 2009 & 2010 & 2011 & 2012 & 2013 & 2014 & 2015 & 2016 & 2017 & All Period \\
\hline AALI & 1,662 & $-0,824$ & $-1,440$ & $-0,377$ & 0,216 & $-0,086$ & $-0,109$ & $-0,100$ & $-4,811$ & $-0,200$ \\
\hline ASII & 0,724 & 0,163 & 4,328 & $-0,401$ & $-0,806$ & 0,083 & $-0,025$ & 0,204 & $-0,518$ & 0,067 \\
\hline $\mathrm{BBCA}$ & 1,767 & $-0,451$ & 1,626 & 0,275 & 0,166 & 0,324 & 1,158 & 0,111 & 0,864 & 0,442 \\
\hline BBRI & $-3,230$ & 0,315 & $-0,210$ & 0,103 & 0,253 & 0,514 & 0,348 & 0,410 & 0,258 & 0,244 \\
\hline BDMN & $-0,813$ & $-0,203$ & $-1,169$ & 0,350 & $-0,459$ & $-0,345$ & 0,134 & $-0,065$ & 0,335 & $-0,041$ \\
\hline BMRI & 023 & 0,020 & 0,044 & 0,417 & 0,022 & 0,402 & 0,159 & 0,023 & 1,213 & 0,120 \\
\hline INDF & 1,189 & 0,067 & $-0,208$ & 1,727 & 0,485 & $-0,277$ & $-0,019$ & 0,231 & $-0,806$ & ,114 \\
\hline KLBF & 0,186 & 0,510 & 0,519 & 0,822 & 0,513 & 0,675 & $-1,714$ & $-0,041$ & $-0,130$ & 0,285 \\
\hline PGAS & $-1,722$ & $-7,316$ & $-0,433$ & 0,468 & 0,112 & $-0,226$ & $-0,534$ & 0,096 & $-0,684$ & $-0,233$ \\
\hline TINS & $-0,217$ & 0,020 & $-0,799$ & $-0,188$ & $-0,170$ & 0,161 & $-1,076$ & 0,414 & $-0,368$ & $-0,125$ \\
\hline TLKM & $-0,724$ & $-444,4$ & 1,167 & 0,488 & 0,796 & 0,112 & 1,607 & 0,070 & $-0,071$ & $-0,003$ \\
\hline UNTR & 0,781 & $-0,335$ & 0,442 & $-0,451$ & $-0,198$ & $-0,494$ & 0,221 & 0,227 & 1,003 & 0,069 \\
\hline UNVR & $-0,465$ & 0,145 & 0,649 & 0,050 & 0,808 & 0,221 & 3,255 & 0,005 & 0,550 & 0,277 \\
\hline
\end{tabular}

Sumber: Data sekunder, diolah.

\section{Kinerja Saham dengan Rasio Sortino}

Pengukuran menggunakan Rasio Sortino serupa dengan Rasio Sharpe hanya saja pada Rasio Sortino, risiko yang diperhitungkan yaitu downside risk. Pada Rasio Sortino menggunakan Minimum Acceptable Return (MAR) sebagai penggati risk-free rate. Standar deviasi untuk ukuran risiko merupakah downside risk dari return di bawah MAR. Adapun hasil perhitungan kinerja sahamsaham yang konsisten dalam Indeks SRI-Kehati periode tahun 2009-2017 dengan menggunakan Rasio Sortino dapat dilihat pada Tabel 6.

Tabel 6. Kinerja Saham dengan Rasio Sortino Periode Tahun 2009 sampai 2017

\begin{tabular}{ccccccccccc}
\hline EMITEN & 2009 & 2010 & 2011 & 2012 & 2013 & 2014 & 2015 & 2016 & 2017 & $\begin{array}{c}\text { All } \\
\text { Period }\end{array}$ \\
\hline AALI & 1,026 & $-0,17$ & $-0,3$ & $-0,22$ & 0,211 & 0,082 & $-0,47$ & $-0,03$ & $-0,54$ & $-0,098$ \\
ASII & 3,563 & 1,032 & 2,376 & $-0,22$ & $-0,44$ & 0,469 & $-0,49$ & 0,643 & 0,031 & 0,260 \\
BBCA & 2,758 & 0,224 & 1,693 & 0,619 & $-0,01$ & 1,368 & $-0,56$ & 0,769 & 2,24 & 0,690 \\
BBRI & 0,119 & 11,63 & $-0,16$ & 0,46 & 1,411 & 1,377 & 1,741 & 2,329 & 1,311 & 1,264 \\
BDMN & $-0,16$ & 0,293 & $-0,44$ & 0,798 & $-0,63$ & $-0,09$ & $-0,06$ & 0,04 & 1,744 & 0,073 \\
BMRI & 0,562 & 0,811 & 0,345 & 0,999 & $-0,1$ & 0,997 & 0,196 & 0,294 & 2,293 & 0,299 \\
INDF & 8,096 & 0,526 & $-0,01$ & 0,66 & 0,275 & 0,072 & $-0,44$ & 0,674 & $-0,21$ & 0,309 \\
KLBF & 1,308 & 1,443 & 0,562 & 1,87 & 0,435 & 1,192 & $-0,91$ & 0,134 & 0,451 & 0,529 \\
PGAS & 0,33 & 0,108 & $-0,26$ & 0,616 & 0,004 & 0,001 & $-0,78$ & 0,359 & $-0,57$ & $-0,132$ \\
TINS & 0,273 & 0,415 & $-0,72$ & $-0,17$ & $-0,23$ & 0,533 & $-1,08$ & 0,99 & $-0,25$ & $-0,075$ \\
TLKM & 0,103 & $-0,48$ & $-0,37$ & 1,315 & 0,388 & 0,529 & 0,669 & 0,37 & 0,224 & 0,167 \\
UNTR & 4,143 & 0,658 & 0,65 & $-0,45$ & $-0,13$ & $-0,31$ & $-0,26$ & 0,638 & 4,002 & 0,209 \\
UNVR & $-0,18$ & 0,56 & 0,415 & 0,137 & 0,757 & 0,88 & $-0,13$ & 0,298 & 2,241 & 0,352 \\
\hline
\end{tabular}

Sumber: Data sekunder, diolah. 
Tabel 6 menunjukkan bahwa nilai minimum hasil pengukuran menggunakan Rasio Sortino periode tahun 2009-2017 adalah sebesar -1,08 yang terjadi pada saham emiten TINS di tahun 2015, sedangkan nilai maksimum adalah sebesar 11,63 yang terjadi pada saham emiten BBRI di tahun 2010. Semakin tinggi (positif) nilai dari Rasio Sortino maka kinerja saham semakin baik. Dan sebaliknya semakin rendah (negatif) nilai dari Rasio Sortino maka kinerja portofolio belum baik. Tabel 6. juga menunjukkan bahwa tidak semua hasil perhitungan Rasio Sortino periode tahun 2009-2017 bernilai positif. Terdapat 3 saham yang menunjukkan kinerja buruk selama periode penelitian yaitu AALI, PGAS, dan TINS. Sedangkan saham yang memiliki nilai rata-rata terbaik berdasarkan hasil pengukuran Rasio Sortino yaitu BBRI dengan hasil rata-rata 1,264.

\section{SIMPULAN, KETERBATASAN, DAN SARAN Simpulan}

Tujuan penelitian ini mengukur kinerja 13 saham yang konsisten dalam Indeks SRI-Kehati periode tahun 2009-2017. Berdasarkan hasil pengukuran dengan menggunakan metode pengukuran Indeks Sharpe, terdapat 10 saham yang menunjukkan nilai positif yang berarti memberikan kinerja yang baik. Saham terbaik berdasarkan pengukuran Indeks Sharpe yaitu BBCA. Untuk pengukuran menggunakan Rasio Treynor diperoleh 9 saham yang menunjukkan kinerja baik dengan saham terbaik yaitu UNVR. Dan berdasarkan hasil pengukuran Jensen Alpha, ada 10 saham yang menunjukkan kinerja saham yang baik.

Hasil pengukuran menggunakan Information Ratio, terdapat 8 saham yang menunjukkan nilai positif. Saham terbaik berdasarkan metode pengukuran Information Ratio yaitu BBCA. Dan untuk hasil pengukuran menggunakan metode Rasio Sortino terdapat 10 saham yang memiliki Rasio Sortino yang lebih besar dari nol, dengan saham BBRI sebagai saham yang memiliki kinerja terbaik.

Secara keseluruhan, saham-saham yang konsisten terdaftar dalam Indeks SRI-Kehati belum tentu menunjukkan kinerja saham yang baik. Dari 13 saham tersebut masih ada saham yang memperoleh hasil negatif pada setiap metode pengukurannya yang berarti masih mempunyai kinerja saham yang buruk. Ada 3 saham yang menunjukkan hasil negatif berdasarkan Indeks Sharpe, Rasio Treynor, Jensen Alpha, Information Ratio dan Rasio Sortino yaitu AALI, PGAS, dan TINS.

\section{Keterbatasan dan Saran}

Keterbatasan dalam penelitian ini yaitu penelitian ini masih berfokus pada kinerja saham individu yang terdaftar dalam Indeks SRI-Kehati. Penelitian ini belum membentuk portofolio saham. Diharapkan kepada penelitian selanjutnya dapat melakukan pembentukan portofolio saham yang terdaftar dalam Indeks SRI-Kehati. Mengenai pengukuran kinerja portofolio saham yang terdaftar dalam Indeks SRI-Kehati, saham-saham yang masih memiliki kinerja kurang baik selama periode penelitian ini belum tentu akan selalu memiliki kinerja yang kurang baik karena terdapat sahamsaham yang bersifat cyclical. Oleh sebab itu penelitian selanjutnya perlu senantiasa melakukan updating dengan periode terbaru.

\section{REFERENSI}

Adam, A. A., \& Shauki, E. R. (2014). Socially Responsible Investment in Malaysia: Behavioral Framework in Evaluating Investors' Decision Making Process. Journal of Cleaner Production, 80, 224-240. doi: 10.1016/j.jclepro.2014.05.075.

Blatt, S. L. (2004). An In-Depth Look at The Information Ratio. Thesis, Worcester Polytechnic Institute. 
Fernita, C., Paramita, E. L., Restuti, M. D., \& Nugroho, P. I. (2014). Corporate Social Responsibility (CSR) Disclosure in Banking Industry in Indonesia. Paper presented at the The 2nd IBEA International Conference on Business, Economics and Accounting, Hong Kong.

Ferruz, L., Gómez-Bezares, F., \& Vargas, M. (2010). Portfolio Theory, CAPM and Performance Measures. In C.-F. Lee, A. Lee \& J. Lee (Eds.), Handbook of Quantitative Finance and Risk Management (pp. 267-281): Springer US.

Hickman, K. A., Teets, W. R., \& Kohls, J. J. (1999). Social Investing and Modern Portofolio Theory. American Business Review, 17(1), 72-78.

Jensen, M. C. (1967). The Performance of Mutual Funds in The Period 1945-1964. Journal of Finance, 23(2), 389-416. doi: http://dx.doi.org/10.2139/ssrn.244153.

Kidd, D. (2011). The Sharpe Ratio and the Information Ratio. Investment Performance Measurement Feature Articles, 1, 1-4.

Nadifa, A. (2016). Analisis Kinerja Reksa Dana Saham dengan Menggunakan Metode Sharpe, Treynor, Jensen dan Information Ratio. Jurnal Universitas Islam Indonesia.

Panait, J., \& Slavescu, E. O. (2012). Using Garch-in-Mean Model to Investigate Volatility and Persistence at Different Frequencies for Bucharest Stock Exchange during 1997-2012. Theoretical and Applied Economics, $19(5$ (570)), 55-76.

Pangestuti, I. R. D., Wahyudi, S., \& Robiyanto, R. (2017). Performance Evaluation of Equity Mutual Funds in Indonesia Period of 2012-2014. Jurnal Keuangan dan Perbankan 21(4), 527-542.

Plantinga, A., \& Scholtens, B. (2001). Socially Responsible Investing and Management Style of Mutual Funds in The Euronext Stock Markets Working Paper.

Putra, M. P. S., Atahau, A. D. R., \& Robiyanto, R. (2018). Cross-Asset Class Portofolio Between Gold and Stocks in Indonesia. Economic Journal of Emerging Markets, 10(1), 69-81. doi: 10.20885/ejem.vol10.iss1.art8.

Renneboog, L., ter Horst, J., \& Zhang, C. (2008). The Price of Ethics and Stakeholder Governance: The Performance of Socially Responsible Mutual Funds. Journal of Corporate Finance, 14(3), 302-322.

Robiyanto, R. (2017). Performance Evaluation and Risk Aversion Rate for Several Stock Indices in Indonesia Stock Exchange. Jurnal Manajemen dan Kewirausahaan, 19(1), 60-64. doi: 10.9744/jmk.19.1.60-64.

Robiyanto, R. (2018). Performance Evaluation of Stock Price Indexes in the Indonesia Stock Exchange. International Research Journal of Business Studies, 10(3), 173-182. doi: https://doi.org/10.21632/iribs.10.3.173-182.

Robiyanto, R., \& Hartanto, A. F. (2018). Contagion Effect dan Integrasi Pasar Modal di Kawasan Asia, Eropa dan Amerika. Jurnal Organisasi dan Manajemen, 14(1), 1-10.

Robiyanto, R., Wahyudi, S., \& Pangestuti, I. R. D. (2017). The Volatility-Variability Hypotheses Testing and Hedging Effectiveness of Precious Metals for the Indonesian and Malaysian Capital Markets. Gadjah Mada International Journal of Business, 19(2), 167-192. doi: 10.22146/gamaijb.26260.

Rollinger, T. N., \& Hoffman, S. T. (2013). Sortino: A 'Sharper'Ratio. Chicago, Illinois: Red Rock Capital. Retrieved from http://www.redrockcapital.com/assets/RedRock_Sortino_white paper.pdf.

Sanidewi, H., \& Paramita, E. L. (2018). The Role of Perceived Green Marketing and Brand Equity on Green Purchasing Decision. Diponegoro International Journal of Business, 1(2), 14-25. 
Sortino, F. A., \& Price, L. N. (1994). Performance Measurement in a Downside Risk Framework. Journal of Investing, 3(3), 59-64. doi: 10.3905/joi.3.3.59.

Treynor, J. L. (1965). How to Rate Management of Investment Funds. Harvard Business Review, 43(1), 63-75.

Zulkafli, A. H., Ahmad, Z., \& M., E. E. (2017). The Performance of Socially Responsible Investments in Indonesia: A Study of the Sri Kehati Index (SKI). Gadjah Mada International Journal of Business, 19(1), 59-76. doi: https://doi.org/10.22146/gamaijb.17959. 